IJ§ER

ISSN: 2149-5939
International Journal of Social Sciences and Education Research

Online, http://dergipark.gov.tr/ijsser

Volume: 1(2), 2015

\title{
An analysis of the play called importance of being earnest with feminist perspective
}

\author{
Çağlar Demir ${ }^{1}$
}

Received Date: $01 / 02$ / 2015

Accepted Date: $01 / 04$ / 2015

\begin{abstract}
Victorian Era is characterized with the power men held in the society. Patriarchal social structure always tended not to let women take positions in the workplace, and social organizations. Victorian England didn't take the women, their education, attitudes and feelings into consideration. The women were only the docile servers at home for Victorian men. However, some intellectual women and male writers wrote striking novels and plays to attract the public and authorities' attention to this mere discrimination. Oscar Wilde was one of those who held this issue. He could affect the public opinion with his delightful and satirizing plays. In this study, Oscar Wilde's well-known play, Importance of Being Ernest was analysed in terms of feminist point of view. The male and female characters of the play, the patriarchal society, attitudes of characters towards marriage were examined under the light of the approaches of some feminist philosophers, such as Simone de Beavoir, Kate Millet, Susan Bordo and Betty Friedan.
\end{abstract}

Keywords: Patriarchy, women, Victorian era, feminism

\section{Introduction}

Feminism emerged as an ideology to advocate women's rights and their equality with men. It criticizes the institutionalized discrimination applied to women in all societies on an equal footing. According to feminist thinkers, women have always been oppressed and humiliated by not giving them an opportunity in politics, art and other social areas.

In Victorian era, men were valued by the patriarchal society. According to dominant ideology, intellect and judgement were the outstanding characteristics of men while women were only the angels of their houses whose physical appearances were appreciated. Patriarchy never let women a powerful position in the family and society.

In literature world, many prominent writers have focused on women issues. One of those writers was Oscar Wilde. He always wrote to protest the authority and supported women's struggle to have the same rights of men. Oscar Wilde saw that disturbing discrimination and shed a light on gender roles in his play called Importance of Being Earnest. Sos Eltis states;

"Disobedience, rebellion, and resistance to the decrees of authority were the central tenets of Oscar Wilde's personal philosophy. The young Wilde viewed rebellion against authority as essential to human advancement and social development. As he observed a few pages later: 'Progress is simply the instinct of self-preservation in humanity, the desire to affirm one's own essence'. Wilde's belief in the overriding importance of disobedience, self-assertion, and dissent endured throughout his life and formed the basis of his individual code. His interest in radical politics, his sympathy with women's struggle to assert their individual rights in opposition to the strictures of Victorian convention, his distrust of all forms of government, influence, and control,

\footnotetext{
${ }^{1}$ English Lecturer, Balıkesir University, School of Foreign Languages, erkandemir508@hotmail.com
} 
Demir, Ç. (2015). An analysis of the play called importance of being earnest with feminist perspective. International Journal of Social Sciences and Education Research, 1 (2), 637-640.

can all be seen as logical consequences of his belief that 'Progress in thought is the assertion of individualism against authority" (Eltis, 1996, p.6)

\section{Marriage in importance of being earnest}

Betty Friedan mentions about marriage in her The Feminine Mystique. She states that family is a comfortable concentration camp. But she is not against marriage. To Friedan, women also can achieve a lot of things outside of marriage. Friedan's views seem parallel with the behaviours of the character Gwendolen in the play. We see Gwendolen, who is a very self-confident, intellectual woman. She is the member of high society. She follows fashion. She is competent on the latest trends. She is very confident of herself. In her dialogue in act one, she says:

"I am smart. I intend to develop in many directions. In fact, I am never wrong." (Wilde, 1912, p .20)

As a Victorian woman, she doesn't focus on only marriage. She also concentrates on her self improvement. She does not see marriage as elimination. Sometimes, she is over-confident. That makes people laugh at her. Because, her judgements are sometimes wrong. For instance, she meets Cecily for the first time and rapidly makes her wrong judgements:

Gwendolen: "Cecily Cardew? What a very sweet name! Something tells me that we are going to be great friends. I like you already more than I can say. My first impressions of people are never wrong." (Wilde, 1912, p. 95)

Later on, she understands that Cecily is interested in her lover. Meanwhile, Cecily is a very romantic, fragile, naive and a lover of nature. She falls in love with uncle Jack's brother. It is easy to deceive her. Cecily is a "submissive" lady just as Susan Bordo in Body and Reproduction of Femininity puts an emphasis on docile bodies and states;

"Through the pursuit of an ever-changing homogenizing, elusive ideal of femininity ...female bodies become docile bodies -bodies whose forces and energies are female are habituated, to external regulation, subjection, transformation and improvement. Femininity has now become a standardised visual image. We learn the rules of what a 'lady' is through bodily discourse - images tell us what face, body shape and clothes we need to have."(Bordo, 1993, p. 2363)

Oscar Wilde conveys his readers that the society where he lives in makes marriage a social obligation. For instance, Algernon and jack have a dialogue about marriage:

"Jack: I am in love with Gwendolen. I have come up to town expressly to propose to her.

Algernon: I thought you had come up for pleasure? I call that business.

Jack: How utterly unromantic you are!" (Wilde, 1912.p. 26)

In this dialogue, Algernon thinks that marriage is not a romantic thing, but business. To have a social status or to fulfil a social obligation, a person must marry. But according jack, marriage is romantic. Algernon reaches his aim of having a respectable name by using marriage institution or a lady. About that point, gender feminist, Catharine Mac Kinnon remarks:

"Then [after liberal feminism], there was a women's movement that criticized...war as male ejaculation. It criticized marriage and the family as institutional crucibles of male privilege....Some criticized sex, including the institution of intercourse, as a strategy and practice in subordination." (MacKinnon, 2005, p.259) 
Demir, Ç. (2015). An analysis of the play called importance of being earnest with feminist perspective. International Journal of Social Sciences and Education Research, 1 (2), 637-640.

\section{Patriarchy}

There is also female abuse in the play. Female characters are deceived by men. Oscar Wilde criticizes men and women of Victorian age through these characters. Male supremacy over women and ideas of male characters about the reasons of marriage are worth being discussed and criticized.

"Women only do that [call each other sister] when they have called each other a lot of other things first" (Wilde, 1912 p. 44)

The male characters, so to speak, insult the woman by saying:

"The only way to behave to a woman is to make love to her, if she is pretty, and to someone else, if she is plain" (Wilde, 1912, p. 42)

The statement of male characters, "behaving woman is making love to her" is of significance in terms of standing for the mentality of male dominated society, which degrades women so immorally.

In fact, woman and man are born equal as Beauvoir says:

"One is not born, but rather one becomes a woman. No biological, psychological or economic fate determines the figure that human female presents in society; it is civilization as a whole that produces this creature, intermediate between male and eunuch, which is described as the feminine." (Beauvoir, 2010, p. 295)

To have social status, Algernon and jack deceive Gwendolen and Cecily by using a name "Ernest".When jack and Algernon marry with their lovers, they will have social status in the society. Especially, Gwendolen does marriage just for "business".

\section{Algernon}

"I really don't see anything romantic in proposing. It is very romantic to be in love. But there is nothing romantic about a definite proposal. Why, one may be accepted. One usually is, I believe. Then the excitement is all over. The very essence of romance is uncertainty. If ever I get married, I will certainly try to forget the fact." (Wilde, 1912, p. 6)

Kate Millet in her Sexual politics (Millet, 1970) criticizes the entire structure of the society, patriarchy. She states that male supremacy prevails in all institutions. Marriage is the traditional pattern of man's power over woman. In the play, especially Algernon's attitude towards marriage support Kate Millet's theory.

On the other hand, Gwendolen bends forward and obeys patriarchal rules and becomes conformist in the play. She believes in class distinction which is a Victorian characteristic and patriarchal view. When her guests offer her cake, she says "Cake is rarely seen at the best houses nowadays".(Wilde, 2005 p.52) She looks down on the people. She always dreams about marriage, marriage and marriage. That is what patriarchy wants.

In act one, Lady Bracknell says:

"I am sorry if We are a little late. Algernon, but I was obliged to call on dear Lady Harbury. I had not been there since her poor husband's death. Inever saw a woman so altered; she looks quite twenty years younger." (Wilde, 1912. p. 20) 
Demir, Ç. (2015). An analysis of the play called importance of being earnest with feminist perspective. International Journal of Social Sciences and Education Research, 1 (2), 637-640.

We understand that there is a different message here. Lady Bracknell implies that lady Harbury changed positively after her husband's death. She became relieved. She saved herself from the chains or restraints of marriage, which is given great value by the victorian society. Oscar wilde tries to attract attention to many married women who are unhappy in this patriarchal society. Marriage is burden In the chapter "Woman: Myth and Reality" of The Second Sex, Simone de Beouvior remarks that men made women " the other" in the society by putting a false aura of mystery around them. Men used this as an excuse not to understand women or their problems and not to help them, and that this stereotyping was always done in societies by the group higher in the hierarchy to the group lower in the hierarchy.

As we know, Lady Bracknell is merchanary, cunning, authoritarian character in the play. Through that figure, Oscar Wilde satirizes the hypocrisy of English aristocracy. She had a good marriage, comfortable life in an aristocratic atmosphere. But at that time, even aristocracy and some women like Lady Bracknell served the patriarchy knowingly or not. Oscar Wilde mocks the aristocracy of that time through Lady Bracknell who says:

"I do not approve of anything that tampers with natural ignorance. Ignorance is like a delicate exotic fruit; touch it and the bloom is gone. The whole theory of modern education is radically unsound. Fortunately, in England, at any rate, education produces no effect whatsoever. If it did, it would prove a serious danger to the upper classes, and probably lead to acts of violence in Grosvenor Square." (Wilde, 1912, p. 33)

A woman in aristocracy values ignorance and tries to make her daughter marry with the man she chooses as the patriarchy imposes on people to marry someone at any account.

\section{Conclusion}

Oscar Wilde wrote Importance of Being Earnest to satirize the patriarchal society he lived in. Wilde portrays the moral hypocrisy of people in Victorian era so masterly in his play. According to Victorian mentality, women can only stay at home and do household, and please their husband. However, the playwright is against the wrongdoings and prejudgements of the Victorian men about the women. That is why, he imagines a society in which women are also powerful and demonstrates that through the role reversals between male and female characters in the play.

\section{References}

Bordo, S (2001). The Body and Reproduction of Femininity. Northon Anthology of Theory and Criticism: New York: W.W.Northon \& Company.

MacKinnon, C.A. (2005). Women's Lives, Men's Laws. USA: Belknap Press of Harvard University Press.

De Beauvoir, S. (2001) The Second Sex, Northon Anthology of Theory and Criticism. New York: W.W.Northon \& Company.

Eltis, S. (1996). Oscar Wilde. Anarchist, Socialist, and Feminist, Series. UK: Oxford English Monographs. Friedan, B. (1993). The Feminine Mystique. New York: Dell.

Millet, K. (1990). Sexual politics. New York: Simon \& Schuster.

Wilde, O. (1994). Importance of being Earnest. UK: Penguin Books. 